\title{
Trade Openness-Government Size Nexus: Compensation Hypothesis Considered for Nigeria
}

\author{
Omo Aregbeyen ${ }^{1, *}$ and Taofik Mohammed Ibrahim² \\ ${ }^{1}$ Department of Economics, University of Ibadan, Ibadan, Nigeria \\ ${ }^{2}$ Nigeria Institute of Social and Economic Research (NISER), Ibadan, Nigeria
}

\begin{abstract}
Over the years, substantial theoretical and empirical studies have been carried out on the trade opennessgovernment size nexus. While a strand of the literature reported positive linkage, the other suggests otherwise. This study contributes to the debate by examining this relationship for Nigeria using the bounds testing approach to cointegration within an ARDL framework proposed by Pesaran et al. (2001). Empirical evidence reveals that government size measured by percentage share of total government expenditure in GDP and share (percent) of recurrent expenditure in GDP significantly affects trade openness in the long run but percentage share of capital expenditure in GDP as a measure of government size does not impact on trade openness in the long run. The results of the standard causality test corroborate these findings. However, the three measures of government size considered significantly affect trade openness in the short run. The major implication for our study therefore is that compensation hypothesis holds for Nigeria. Thus, the government need to continue to expand its expenditure in order to cushion the effect of increase in risk caused by rising trade openness.
\end{abstract}

Keywords: Compensation Hypothesis, trade openness, government size, Bound Test, Nigeria.

\section{INTRODUCTION}

The literature on macroeconomics and public finance pointed to a defined association between government size and the extent of trade openness in an economy. This followed from the pioneering studies of Cameron (1978) and Ruggie (1982) that marked the beginning of rigorous theoretical and empirical discussions on this relationship. Ruggie, following the observance of a positive correlation between the government size and trade openness puts forward the compensation hypothesis- positing that trade openness leads to an increase in the size of the government. The compensating hypothesis as furthered expounded on by Rodrik $(1997,1998)$ postulates that increase in trade openness may stimulate increase in government size in form of redistributive public expenditure in order to compensate for increasing risk caused by possible international market turbulence. The argument runs that increased trade openness may increase risk among the citizens thereby making them to demand for more redistributive government expenditure in order to compensate for the risk. In this connection, the government sector is seen as a safe sector in terms of employment and income thereby making it easier to isolate its function over external risk by increasing its impact to the entire economy.

\footnotetext{
*Address correspondence to this author at the Department of Economics, University of Ibadan, Ibadan, Nigeria; Tel: +234 803077 7150;

E-mail: omoaregbeyen@gmail.com

Jel Classification: F41, H11.
}

In Nigeria, casual observations indicated that the government size has increased in response to extensive trade openness. This nexus has attracted significant discussions but without empirical evidence. Yet empirical evidences on government size and trade openness abound in the literature for the developed countries, and few developing countries. This study therefore is aimed at enriching the discussions on government size and trade openness nexus in Nigeria with empirical evidence as well as broadens the extant literature generally.

The rest of the paper is organised into five (5) sections as follows: Section II examines the trend and behaviour of component of government size and trade openness in Nigeria while Section III is a review of previous studies. The methodological approach is laid out in Section IV, while empirical results are presented in section V. Section VI concludes and draws policy implications.

\section{STYLIZED FACT ON GOVERNMENT SPENDING PATTERN AND TRADE OPENNESS PROFILE IN NIGERIA (1970-2012)}

The trend and pattern of government size captured by spending and trade openness (measured by the sum of exports and imports as proportion of gross domestic product) during 1970-2012 are depicted in Figures 1 to 3 .

Figure 1 components are plotted using the logarithmic forms of the data. It showed the trend of capital, recurrent and total expenditures. There was on 
the average consistent increase in total and recurrent expenditure while capital expenditure fluctuated. The trend in export, import and trade, captured in Figure 2, showed that export and import (share of GDP) moved in the same direction (this is because Nigeria is characterised by high crude oil export and refined oil import). They both increased all through the period of study except for 2012 where a fall in import does not correspond to the increase in export. This can partly be attributed to the on-going reforms in the oil sector, which resulted in a $4.4 \%$ fall in oil sector imports (CBN, 2012). Accordingly and as expected, total trade openness fluctuated over the period.

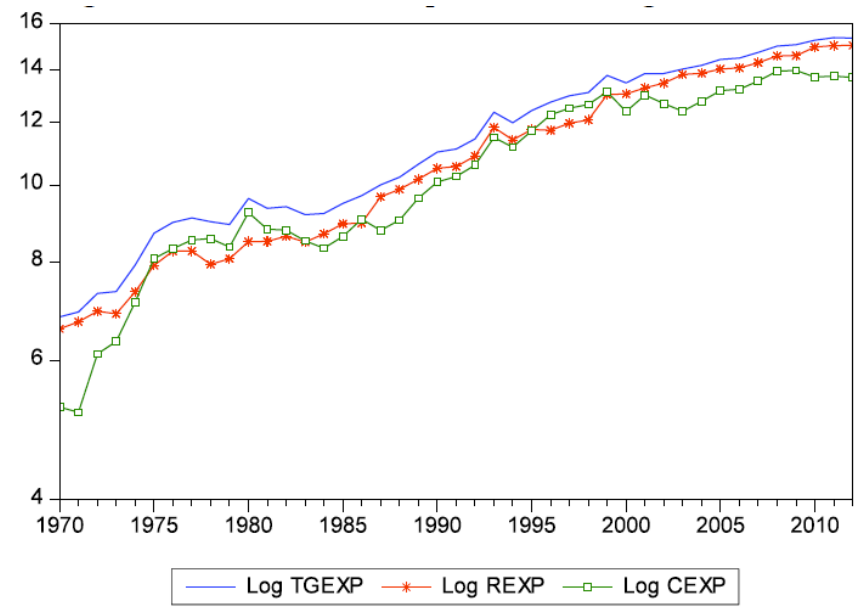

Figure 1: Trend of Total Expenditures in Nigeria (19702012).

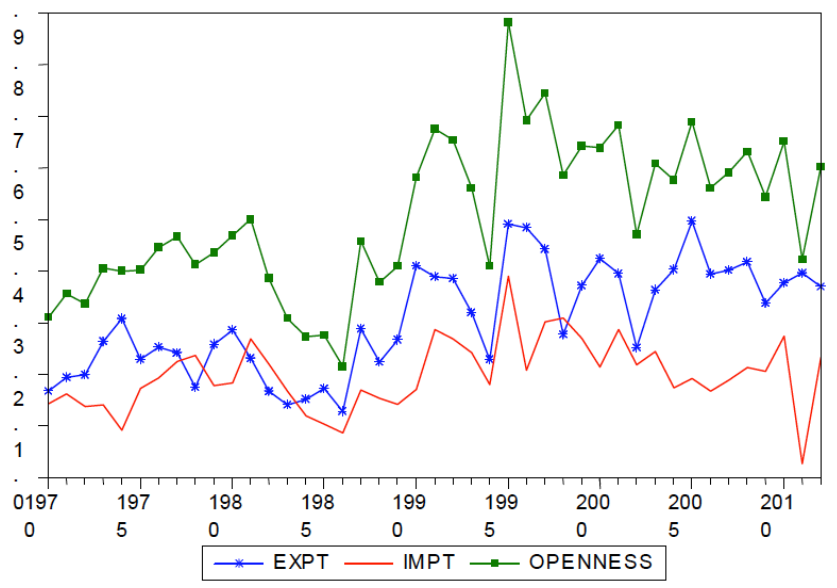

Figure 2: Trade Openness in Nigeria (1970-2012).

Figure 3 showed the trend in government size mesured alternatively by total government expenditure, capital expnditure and recurrent expenditure, all share of GDP in relation to total trade openness. From the figure, it could be seen that on the average government size increased in response to the expansion in trade openess.

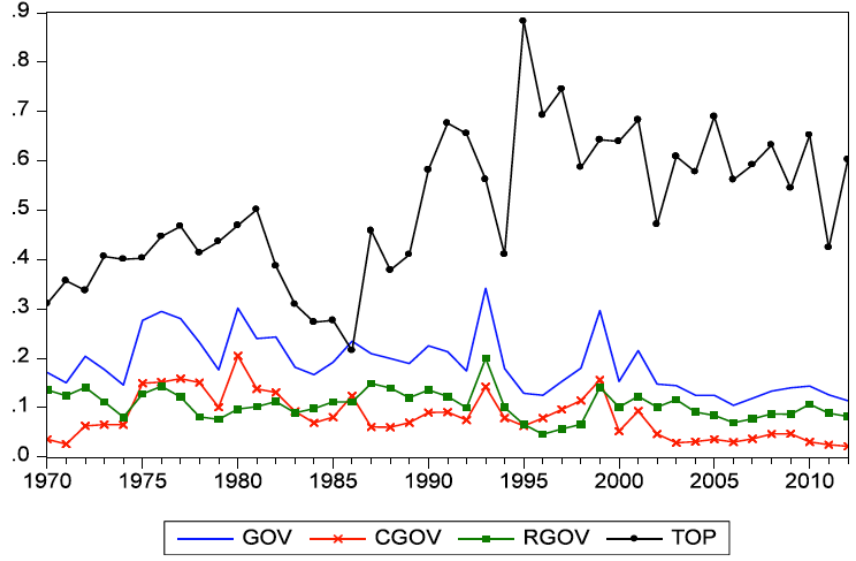

Figure 3: Government Size and Trade Openness in Nigeria (1970-2012).

\section{REVIEW OF PREVIOUS STUDIES}

Indeed, many studies have tested the validity of the hypothesis. These studies included cross-country and specific country studies, and produced mixed results. This review covered a broad spectrum of these studies and is ordered by the year the studies were conducted.

Starting with Alesina and Wacziarg (1998), they utilized cross-sectional data comprising Latin American, Sub-Saharan Africa, South East Asia and OECD countries to examine the nexus among trade openness, country size and government size covering the period 1960-1989. The reported results in the main showed that country size is negatively related to government size, and that it is also negatively related to trade openness.

Garrett (2000) explored the interactive effects of trade and capital mobility on government spending for the largest possible sample of countries (over 1000) around the world during 1970-1995. He focused on testing directly whether capital mobility constrains public spending on its own, or mitigates the effects of trade as Rodrik $(1997,1998)$ summarised. In addition, he analysed these relationships not only with respect to levels of spending, trade and capital mobility, but also for changes over time in these variables. His results showed a significant positive relationship between levels of trade and levels of government spending. Further findings concerning the relationships among changes in trade, capital mobility and government spending (measured as the difference between 19701984 averages and those for 1985-1995), suggested that countries in which trade grew more rapidly after 1985 tended to have public economies that grew less quickly, and this became exacerbated in countries where capital mobility increased quickly. 
Using a simple analysis of correlation coefficients, Alvarez, Pascual and Romero (2003) examined the relationship between trade openness and public expenditure in the EU-15 between 1998 and 2000 and found a negative relationship. Sanz and Velázquez (2003) investigated the effects of trade openness and financial openness proxy by averaged stock of inward and outward foreign direct investments on government size in Spain. Their finding suggested a positive effect of trade openness on the share of health and social security expenditures in total government expenditures and a negative effect on education, housing, transport and communication shares of public expenditures. They argued that countries with high stock of FDI experienced more risk in labor mobility as multinational companies change their location easily compared to domestic or national companies. This in turn reduces total employment and wages in the economy.

Islam (2004) analyzed the relationship between government size and economic openness for six member countries of the Organizations for Economic Co-operation and Development (OECD) namely Australia, Canada, England, Norway, Sweden, and the United State of America. The findings indicated the existence of a long run relationship between government size and trade openness for USA and Canada, but non for the other four countries. In contrast, Molana et al. (2004), in an earlier study for Spain covering the period 1948-1998, observed no long run cointegration between trade openness (the sum of exports and imports as proportion of gross domestic product) and public expenditure on goods and services. Causality test also showed no causal relationship between the two. They, however, took cognizance of the fact that the unsuitable measurement of the variables used in their analysis, might be the possible reasons for their results.

Garen and Trask (2005) in their study on openness and size of government in the US used non-budgetary measures to proxy government size and also revealed that the relationship is not very robust but positive. Furthermore, Liberatti (2006) in his study on trade openness, financial openness and government size for 16 European countries, USA, Canada and Australia confirmed the non-robustness of the relationship between trade openness and government size. Using Vector Error Correction Model (VECM), Khalid (2005) examined the long-and-short run relationship between government size and trade openness in the Kingdom of Saudi-Arabia. His results showed the existence of a long run relationship between government size and openness, while the causality test indicates a unidirectional causal relationship that runs from government size to trade openness.

Swee-Hui Kueh et al. (2008) used the Autoregressive Distributed Lag [ARDL] bounds testing approach to examine the relationship between trade openness and government expenditure for the Association of Southeast Asian Nations [ASEAN] countries namely Indonesia, Malaysia, Philippines and Thailand from 1974-2006. The reported results indicated a significant positive long-run linkage between government expenditure and trade openness for the four countries. Benarroch and Pandey (2008) also examined whether there exists a positive association between trade openness and government consumption using cross-country and panel regressions. This was achieved by testing for causality between external risk and government size using the Granger causality test for panel data based on the dynamic panel estimation model of Arellano and Bond (1991). The results indicated that larger government size leads to lower openness. In other words, a negative association between trade openness and government size.

Similarly, Rivas et al., (2009) reported a positive long run relationship between public expenditure and trade openness for Spain during the period 1960-2000. Epifani and Gancia also in (2009) explored two different channels and hypothetical data to analyse the relationship between trade openness and government size. Their findings indicated the existence of a positive relationship between trade openness and government size. Ram (2009) presented contrasting results. He examined the link among openness, country size and government size with a 41 year panel data covering the period 1960-2000 for 154 countries. Pooled OLS estimates supported previous evidence of negative association between country size and government size and between openness and government size. But when cross- country heterogeneity was accounted for, through fixed effects model, there was little evidence of a negative association of country size with either government size or openness. Ram concluded that it did not seem likely that positive association between openness and government size arises due to the mediating role of country size.

Shahbaz, Rehman and Amir (2010) utilized the Fully Modified Ordinary Least Square (FMOLS) cointegration approach and Error Correction Mechanism (ECM) to determine the long and short run 
nexus between trade openness and government size in Pakistan from 1971 to 2006 . Their findings support the compensating hypothesis; that is, the existence of a positive and significant long and short run relationship between trade openness and government size.

Benarroch and Pandey (2012), extending on their earlier study of 2008 examined the causal relationship between trade openness and government size using both aggregate and disaggregated government expenditure data, including data on social security for 119 countries covering the 1972-2000. The sampled countries were classified into high and low growth countries, respectively. The dynamic panel estimation model/technique was utilized. The results from the fixed effects model showed there was no positive causal relationship for aggregate government expenditures. Separate tests for high versus low countries showed that these results hold for both groups of countries. Similar results were obtained using disaggregated data. The only evidence of a robust, statistically significant, positive causal relationship was found between openness and education expenditures in low income countries. There was no positive causal relationship whatsoever between social security and openness. The authors therefore concluded that there was no evidence to support the relationship as suggested by Rodrik (1998).

Nahidi et al. (2013) investigated the relationship between trade openness, financial openness and government size for Economic Cooperation Organization countries comprising Azerbaijan, Iran, Kazakhstan, Kyrgyzstan, Pakistan, Tajikistan and Turkey during 2000-2009. The reported results suggested a positive long run relationship between trade openness and government size and a negative relationship between financial openness and government size. For Turkey, Aydogus and Topcu (2013) used residual based cointegration and the standard causality test to investigate the long-run and causal relationship between trade and openness and government size during 1974 and 2011. Their results reveal negative and significant relationships between the two variables. And Liberati (2013) reexamined the relationship between government size and trade openness using an unbalanced panel of 156 countries variously observed during 1962 to 2009 . The results reported showed on one hand that country size is not relevant to determine the sign of the relationship between government size and economic openness, but on the other confirmed the relevance of the crosscountry heterogeneity as suggested by Ram (2009) to buttress the compensation hypothesis was weak. Consequently, the author concluded that the compensation hypothesis cannot be assigned general validity on this ground. However, was acknowledged that these results were robust to alternative specifications of the explanatory variables.

Parvizkhanlou (2014) looked at the relationship between trade openness, financial openness and government size in seven Economic Cooperation Organization (ECO) countries (namely Azerbaijan, Iran, Kazakhstan, Kyrgyz Republic, Pakistan, Tajikistan and Turkey) during 2000-2009. The results indicated that more trade openness will increase government size (proxied by government consumption expenditures) as hypothesized by Cameroon (1978) and Roderick (1998). In contrast, financial openness was negatively related with the government size.

In summary, it obvious from the foregoing review that the empirical relationship between government size and trade openness has varied from study to study; country to country and by the measures of government size and the methodology adopted.

\section{VI. METHODOLOGY}

\section{VI.1. Estimation Method}

From the literature survey above, the relationship between trade openness and government size can either be unidirectional or bi-directional. Thus, the functional form is expressed as:

$T O P=f(G O V)$

Where: TOP is trade openness (the sum of exports and imports on Gross Domestic Product - GDP) and GOV is measured as the share (percent) of government expenditure in GDP.

Disaggregating government expenditure into recurrent and capital expenditures gives us two additional measurement of government size. Therefore, we have two other possible functional forms on the relationship between trade openness and government size thus:

$$
\begin{aligned}
& T O P=f(R G O V) \\
& T O P=f(C G O V)
\end{aligned}
$$


Where: RGOV and CGOV represent the share (percent) of recurrent and capital expenditure in GDP, respectively.

The Autoregressive Distributed Lag (ARDL) model specification was adopted to estimate these functional forms empirically. The ARDL co-integration test (which is popularly known as the bound test) was utilised to determine the long-run relationships and dynamic interactions between trade openness and the alternative measures of government size. Three reasons inform the decision of adopting this approach. These are: compared to other co-integration methods like Johansen; Engle and Granger, the bounds test allows the co-integration relationship to be estimated by OLS once the lag order of the model is identified; there is no need to conduct unit root test implying that the regressors can be either $\mathrm{I}(0)$, purely $\mathrm{I}(1)$ or mutually co-integrated; and the long-run and short run parameters of the models are simultaneously determined.

The ARDL model specifications for the three functional forms of our model are expressed thus:

$$
\begin{aligned}
& \Delta \ln T O P_{t}=a_{0}+a_{1} \ln T O P_{t-1}+a_{2} \ln G O V_{t-1} \\
& +\sum_{i=1}^{j} \alpha_{i} \Delta \ln T O P_{t-i}+\sum_{i=1}^{j} \gamma_{i} \Delta \ln G O V_{t-i}+\varepsilon_{t}
\end{aligned}
$$

$\Delta \ln T O P_{t}=\phi_{0}+\phi_{1} \ln T O P_{t-1}+\phi_{2} \ln R G O V_{t-1}$

$+\sum_{i=1}^{n} \beta_{i} \Delta \ln T O P_{t-i}+\sum_{i=1}^{n} \lambda_{i} \Delta \ln R G O V_{t-i}+e_{t}$

$\Delta \ln T O P_{t}=b_{0}+b_{1} \ln T O P_{t-1}+b_{2} \ln C G O V_{t-1}$

$+\sum_{i=1}^{m} \theta_{i} \Delta \ln T O P_{t-i}+\sum_{i=1}^{m} \kappa_{i} \Delta \ln C G O V_{t-i}+\mu_{t}$

Where: $\Delta$ denotes a first difference operator; In represents natural logarithmic transformation; $a_{0}, \phi_{0}$ and $b_{0}$ are intercept while $\varepsilon, e$ and $\mu$ are white noise error terms.

The bound test approach is based on the Wald test ( $F$ statistic), by imposing restrictions on the long-run estimated coefficients of one period lagged level of trade openness and government size in equations (4) to (6) to be equal to zero. That is, Ho: $a_{1}=a_{2}=0$; Ho: $\phi_{1}=\phi_{2}=0$; and Ho: $b_{1}=b_{2}=0$. The calculated Fstatistic is compared to the tabulated critical value in (Pesaran et. al. (2001). The decision rule is that if computed F-statistic falls below the lower bound value, the null hypothesis (no co-integration) cannot be rejected. Contrarily, if the computed F-statistic exceeds the upper bound value, then it is concluded that trade openness and government size are co-integrated.

The error correction model was used to capture the speed of adjustments of trade openness and government size in the models. This is because to immediately restore equilibrium may not be possible due to the lags and adjustment process used to capture changes in any of the factors affecting trade openness and government size overtime. Thus, these models are expressed below:

$$
\begin{aligned}
& \Delta \ln T O P_{t}=a_{0}+\sum_{i=1}^{j} \alpha_{i} \Delta \ln T O P_{t-i}+\sum_{i=1}^{j} \gamma_{i} \Delta \ln G O V_{t-i} \\
& +\partial_{t} e c t_{t-1}+\varepsilon_{t}
\end{aligned}
$$

$$
\begin{aligned}
& \Delta \ln T O P_{t}=\phi_{0}+\sum_{i=1}^{n} \beta_{i} \Delta \ln T O P_{t-i}+\sum_{i=1}^{n} \lambda_{i} \Delta \ln R G O V_{t-i} \\
& +\ell_{t} e c t_{t-1}+e_{t}
\end{aligned}
$$

$$
\begin{aligned}
& \Delta \ln T O P_{t}=b_{0}+\sum_{i=1}^{m} \theta_{i} \Delta \ln T O P_{t-i}+\sum_{i=1}^{m} \kappa_{i} \Delta \ln C G O V_{t-i} \\
& +\vartheta_{t} e c t_{t-1}+\mu_{t}
\end{aligned}
$$

\section{Where:}

$\mathrm{j}, \mathrm{n}$, and $\mathrm{m}=$ lag length for the Unrestricted ErrorCorrection Model (UECM)

$e c t_{t-1}=$ the error correction term lagged for one period

$\partial$, $\ell$, and $\vartheta=$ the coefficients for measuring speed of adjustment in equation 7,8 and 9 respectively. Other variables are as defined earlier.

In agreement with the argument in the literature that it might be important to determine the direction of causality between government size and trade openness, and following on the lead by Benarroch and Pandey (2012); and Aydogus and Topcu, (2013), we conducted the standard pairwise causality technique to determine the direction of causality between our various measures of government size and trade openness.

\section{IV.2. Sources of Data}

This study employed annual data that covered the period 1970-2012. The data were sourced from the Central Bank of Nigeria Statistical Bulletin (2012). 
Table 1: Bound Testing for Cointegration

\begin{tabular}{|c|c|c|c|c|}
\hline & & \multicolumn{2}{|c|}{ Critical Bound } & Upper \\
\hline & F-stat & Lower & 5.73 & 1 \\
\hline \hline Equation (4) & 5.9133 & 4.94 & 5.73 & 1 \\
\hline Equation (5) & 8.2453 & 4.94 & 5.73 & 1 \\
\hline
\end{tabular}

Notes: Asymptotic critical value bounds are obtained from Table $\mathrm{Cl}$ (iii); Case III: unrestricted intercept and no trend for k=1 (Pesaran et al., 2001 ).

\section{EMPIRICAL RESULTS}

The bounds test results for equations (4), (5) and (6) are presented in Table 1. From the table, the computed F-Statistic for equation (4), (5) and (6) is $5.9133,8.2453$ and 5.2453 respectively. These values exceeded the upper bounds critical value of 5.73 at the $5 \%$ significance level except for equation (6). This implies that there exist a long run relationship between trade openness and total government expenditure as a measure of government size; trade openness and recurrent expenditure as a measure of government size while no long-run relationship was found between trade openness and capital expenditure as a measure of government size.

In Table 2, we present the estimates of long run association between trade openness and government size(s). The coefficients are $0.59,2.05$ and 0.19 for equation 4, 5 and 6 respectively. The coefficients of GOV and RGOV are significant while that of CGOV is insignificant. The estimates suggest that a $10 \%$ increase in total government expenditure would lead to $5.9 \%$ increase in trade openness while $10 \%$ increase in recurrent expenditure would results to $20.5 \%$ increase in trade openness. Though, the coefficient of capital expenditure is positive but insignificant indicates that in the long run, capital expenditure does not affect trade openness in Nigeria.
Following the long-run analysis, we examine the effect of changes in government size on trade openness by estimating an unrestricted error correction model. Table 3 showed that the lagged values of the residual $\left(E C M_{t-1}\right)$ in equations (7), (8) and (9) which measures the speed of adjustment of the models to equilibrium are rightly signed, significant and are all less than one. This means that approximately $26 \%$, $23 \%$ and $27 \%$ of the discrepancies in the previous year is adjusted for in the current year for equation (7), (8) and (9), respectively. The results also reveal that $\triangle G O V(-1), \quad \Delta R G O V(-1)$ and $\Delta \operatorname{CGOV}(-1)$ impact positively on trade openness in the short run with the coefficient of $\triangle \mathrm{CGOV}$ been the highest.

According to Bahmani-Oskooee and Brooks (1999), the existence of a cointegration does not necessarily imply that the estimated coefficients are stable. They therefore proposed that cumulative sum (CUSUM) and cumulative sum of squares (CUSUMSQ) stability tests based on the recursive regression residuals should be conducted to ascertain the stability of the estimated parameter. The outputs of these tests are presented in Figure 4. From the figure, it is evident that the plotted statistics for the three equations fall inside the critical bounds of $5 \%$ significance indicating that the estimated parameters are stable.

The results of the causality test presented in Table 4 showed that there is a uni-directional causal

Table 2: The Estimated (ARDL) Expenditure Model

\begin{tabular}{|c|c|c|c|}
\hline Variables & Equation (4) & Equation (5) & Equation (6) \\
\hline \hline C & $0.30^{*}$ & $0.39^{* *}$ & $0.20^{*}$ \\
\hline GOV(-1) & $0.59^{* *}$ & & 0.19 \\
\hline RGOV(-1) & & & $0.05^{*}$ \\
\hline CGOV(-1) & $0.56[0.75]$ & $0.78[0.66]$ & $0.73]$ \\
\hline Jaque-Bera & 0.51 & 0.61 & 1.81 \\
\hline Adjusted R square & 1.85 & 41 & 1.74 \\
\hline Durbin-Watson & 41 & & 41 \\
\hline Observation & & & \\
\hline
\end{tabular}

Notes: ${ }^{*}$ and ${ }^{* *}$ denote significance at $1 \%$ and $5 \%$ respectively. Sample: 1970 to 2012 
Table 3: Results of the ARDL Short-run Relationship

\begin{tabular}{|c|c|c|c|}
\hline Variables & Equation (7) & Equation (8) & Equation (9) \\
\hline \hline $\mathrm{C}$ & 0.01 & 0.02 & 0.01 \\
\hline$\Delta$ TOP(-1) & $0.37^{* *}$ & $0.34^{* *}$ & $0.31^{*}$ \\
\hline$\Delta$ GOV(-1) & $0.44^{* *}$ & $1.38^{*}$ & \\
\hline$\Delta$ RGOV(-1) & & & $1.77^{* *}$ \\
\hline$\Delta$ CGOV(-1) & & $-0.23^{* *}$ & $-0.27^{*}$ \\
\hline ECM(-1) & $-0.26^{* *}$ & & \\
\hline
\end{tabular}

Note: $\left({ }^{*}\right)$ and $\left({ }^{* *}\right)$ indicates $1 \%$ and $5 \%$ significance level respectively.
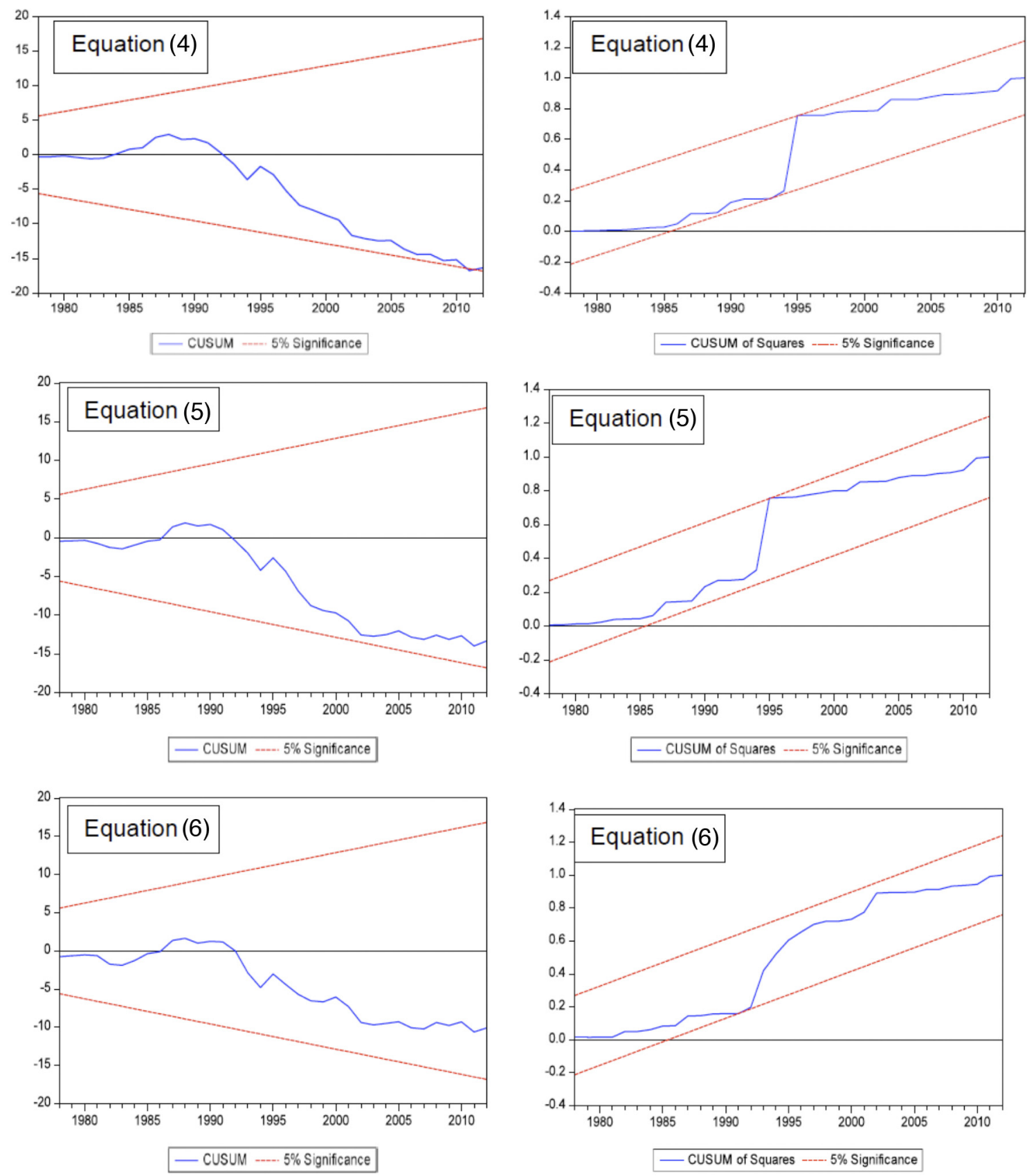

Figure 4: CUSUM and CUSUM square stability tests for Equations (4), (5) and (6). 
Table 4: Standard Causality Test for the Relationship between Trade Openness and Measurements of Government Size

\begin{tabular}{|c|c|c|c|}
\hline Null Hypothesis & Obs. & F-Statistics & Probability \\
\hline \hline TOP does not Granger cause GOV & 41 & 3.68 & $0.0231^{* *}$ \\
\hline GOV does not Granger cause TOP & 41 & 1.32 & 0.1128 \\
\hline TOP does not Granger cause RGOV & 41 & 6.12 & $0.0051^{*}$ \\
\hline RGOV does not Granger cause TOP & 41 & 1.64 & 0.2090 \\
\hline TOP does not Granger cause CGOV & 41 & 0.20 & 0.8224 \\
\hline CGOV does not Granger cause TOP & 41 & 0.44 & 0.6456 \\
\hline
\end{tabular}

Note: $\left({ }^{*}\right)$ and $\left({ }^{* *}\right)$ indicates $1 \%$ and $5 \%$ significance level respectively.

relationship from trade openness to two measures of government size (total government expenditures and recurrent expenditures). There was no causality whatsoever between trade openness and capital expenditures.

\section{CONCLUDING REMARK}

This study has probed the relationship between trade openness and government size in Nigeria, utilizing data from 1970-2012. The Unrestricted Error Correction Model-Bounds Test proposed by Pesaran et al. (2001) to investigate the long -run and short -run relationships between the two variables was employed and complemented with causality tests. The empirical results showed that trade openness and government size when measured by percentage share of total government expenditure in GDP and percentage share of recurrent expenditure in GDP are cointegrated while government size measured as the share (percent) of capital expenditure in GDP and trade openness are not cointegrated. The causality tests provide relatively strong support for a causal relationship between openness and aggregate government expenditures on one hand and disaggregated (recurrent) government expenditure on the other hand. Going by these results, we concluded that the compensation hypothesis holds in Nigeria. Accordingly, government need to continue to expand its expenditure in order to cushion the effect of increase in risk caused by rising trade openness.

\section{REFERENCES}

Alesina, Alberto and Wacziarg, Romain (1998), "Openness, Country Size and Government", Journal of Public Economics, 69, 305-321. http://dx.doi.org/10.1016/S0047-2727(98)00010-3

Alvarez, S., Pascual, M. and Romero, D. (2003), "Protección social, globalizacióny crecimiento económico", Hacienda Pública española, Monografía, pp. 63-77.

Arellano, Manuel and Bond, Stephen (1991), "Some Tests of Specification for Panel Data: Monte Carlo Evidence and
Application to Employment Equations", The Review of Economic Studies, 58,277-297.

http://dx.doi.org/10.2307/2297968

Aydogus, Ismail and Topcu, Mert (2013). An Investigation of CoIntegration and Causality between Trade Openness and Government Size in Turkey, International Journal of Economics and Financial Issues, Vol. 3, No. 2, pp.319-323.

Bahmani-Oskooee, Moshen, Brooks, J. Tagggert (1999), "Bilateral Jcurve Between US and Her Trading Partners", Weltwirtschaftliches Archiv, 135, 156-165. http://dx.doi.org/10.1007/BF02708163

Benarroch, Micheal and Pandey, Manish (2008), "Trade Openness and Government Size", Economic Letters, 101, 157-159 http://dx.doi.org/10.1016/j.econlet.2008.06.016

Benarroch, Micheal and Pandey, Manish (2012), "The Relationship between Trade Openness and Government Size: Does Disaggregating Government Expenditure Matter? Journal of Macroeconomics, 34, 239-252.

http://dx.doi.org/10.1016/j.jmacro.2011.11.002

Cameron, David. R. (1978), "The Expansion of the Public Economy: A Comparative Analysis". American Political Science Review, $72,237-269$ http://dx.doi.org/10.2307/1954537

Central Bank of Nigeria (CBN) (2012), Annual Statistical Bulletin.

Epifani, Paolo. and Gancia, Gino. (2009). Openness, Government Size and the terms of Trade, Review of Economic Studies, Vol. 76 (2), pp. 629-668. http://dx.doi.org/10.1111/j.1467-937X.2009.00546.x

Garen John., Trask, Kathleen (2005), "Do More Open Economies have Bigger Governments? Another Look", Journal of Development Economics, 77: 533-551. http://dx.doi.org/10.1016/j.jdeveco.2004.04.002

Garrett, Geoffrey. (2000): "Globalization and Government Spending around the World", Studies in Comparative International Development, 35 (4), pp. 3-29. http://dx.doi.org/10.1007/BF02732706

Islam, Muhammad (2004), "The Long Run Relationship between Openness and Government Size: Evidence from Bounds Test", Applied Economics, 36(9), 995-1000. http://dx.doi.org/10.1080/0003684042000233221

Khalid, H.A. Alqudair (2005), "Does Trade Openness lead to Big Government Size"? Paper

presented by the Ecomod Network and the Middle East Economic Association

held at Free University of Brussels Belgium.

Liberati, Paolo. (2013), "Government Size and Trade Openness: Some Additional Insights", Munich Personal RePEc Archive (MPRA) Paper No. 43561. January. Http://mpra.ub.unimeenchen.de/43561. Retrived 13th August, 2014. 
Liberati, Paolo. (2006), "Trade Openness, Financial Openness and Government Size", Università di Urbino "Carlo Bo", ISE.

Molana, H., Montagna, C., and Violato M. (2004), "On the Causal Relationship between Trade Openness and Government Size: Evidence from 23 OECD Countries", mimeo.

Nahidi, Mohammadreza.M., Parvizkhanlou, Karan, J. and Badri, Arashketabforoush. (2013), "An Impact of Trade and Financial-Openness on Government Size: A Case Study for ECO", International Journal of Advanced Studies in Humanities and Social Science, Vol. 1, Issue 8, pp. 10131017

Parvizkhanlou, Karam.F. (2014), "An Impact of Trade and Financial Openness on Government Size: A Case Study for ECO", IRC'S International Journal of Multidisciplinary Research in Social \& Management Sciences, Vol. 2, no. 2, pp.1-4.

Pesaran, M. Hashem., Shin, Yongcheol and Smith, J. Richard (2001), "Bounds Testing Approaches to the Analysis of Level Relationships", Journal of Applied Econometrics, 16, 289326. http://dx.doi.org/10.1002/jae.616

Rivas, $M^{a}$ Dolores. G., Sort, Marcela. S. and Rodríguez, Estela. S. (2009), "The Relationship between Trade Openness and Public Expenditure". The Spanish case, 1960-2000. Documento de Trabajo 2009-06, Facultad de Ciencias Económicas y Empresariales, Universidad de Zaragoza.
Rodrik, Dani (1997), "Has Globalization Gone Too Far”, Institute for International Economics.Washington D.C.

Rodrik, Dani. (1998), "Why Do More Open Economies Have Bigger Governments"? Journal of Political Economy, 106 (5), 9971032. http://dx.doi.org/10.1086/250038

Ruggie, John.G. (1982), “International Regimes, Transactions, and Change: Embedded Liberalism in the Postwar Economic Order", International Organization, 36, 379-415. http://dx.doi.org/10.1017/S0020818300018993

Sanz, Ismael and Velázquez, Francisco. J. (2003), "Does Globalization increase Government Size? An Analysis of the Effects of Foreign Direct Investment on Total Government Expenditures and its Components", mimeo.

Shahbaz, M., Rehman, H.Ur, and Amir, N. (2010), "The Impact of Trade and Financial-

Openness on Government Size: A Case Study of Pakistan", Journal of Quality and Technology Management, Vol. VI, Issue 1, pg. $105-118$.

Swee Kueh, Jerome Swee-Hui and Puah, Chin-Hong and Wong, Chiew-Meu (2008), "Bounds Estimation for Trade Openness and Government Expenditure Nexus of ASEAN-4 Countries", MPRA Paper No. 12351.

DOI: http://dx.doi.org/10.6000/1929-7092.2014.03.27

(C) 2014 Aregbeyen and Ibrahim; Licensee Lifescience Global.

This is an open access article licensed under the terms of the Creative Commons Attribution Non-Commercial License (http://creativecommons.org/licenses/by-nc/3.0/) which permits unrestricted, non-commercial use, distribution and reproduction in any medium, provided the work is properly cited. 